ГЕОЛОГИЯ, ПОИСКИ И РАЗВЕДКА

ТВЕРДЫХ ПОЛЕЗНЫХ ИСКОПАЕМЫХ, МИНЕРАГЕНИЯ

УДК 550.814:669.21

DOI: 10.46698/VNC.2021.99.14.010

Оригинальная статья

Комплексная оценка параметров и закономерностей распределения благороАНЫх мета^^ов влияющих НО ИХ ПРОАУКТИВНОСТЬ

\author{
И. И. Босиков ${ }^{\mathbb{D} 1}$, Р. В. Клюев ${ }^{\mathbb{D} 2}$, К. В. Темиров ${ }^{(\mathbb{D} 3}$, А. И. Мазко ${ }^{\mathbb{D} 1}$ \\ ${ }^{1}$ Северо-Кавказский горно-металлургический институт (государственный \\ технологический университет), Россия, 362021, РСО-Алания, г. Владикавказ, ул. \\ Николаева, 44; \\ ${ }^{2}$ Московский политехнический университет, Россия, 107203, г. Москва, ул. Большая \\ Семеновская, 38, e-mail: kluev-roman @ rambler. ru; \\ зУправление по обеспечению реализации национальных проектов в Республике \\ Северная Осетия-Алания (Проектный офис РСО-Алания), Россия, 362040, РСО-Алания, \\ г. Владикавказ, пл. Ленина, д. 2 \\ Статья поступила: 06.08.2021, доработана: 21.08.2021, принята кпубликации: 03.09.2021
}

Резюме: Актуальность работы. За последние десятилетия, начиная с шестидесятых годов двадцатого века, производство благородных металлов неуклонно возрастает на $12 \%$ в год. Причём, спрос опережает предложение. Это связано отчасти с тем, что благородные металлы являются эквивалентом стоимости человеческого труда, а с другой стороны возрастает их промышленное использование, основанное на свойствах элементов этой группы металлов. Цель исследований: провести анализ и комплексную оценку параметров и закономерностей распределения благородных металлов (БМ) влияющих на их продуктивность. Методика исследований. Проводился минералого-петрографический анализ шлихов из скважин, пробирный анализ золота из разведочных скважин, фрациальный и фрормационный анализ, гранулометрический анализ. Результаты исследований. Крупность золота в коренных месторождениях оказывает прямое и решающее влияние на продуктивность образованных ими россыпей: чем мельче золото, тем ниже продуктивность. Объясняется это, тем что, мелкие и субмикроскопические зерна золота обладают большой миграционной способностью в водно-аллювиальной среде, такое золото не будет образовывать крупных россыпных месторождений. По результатам пробирных анализов золота из разведочных скважин, средняя шлиховая пробность металла в пределах площади данного подсчета запасов составляет $890,1 \%$ и колеблется в основном в диапазоне 889-898, в одном случае понижается до 840 (линия 24). Лигатурная пробность меняется незначительно, в пределах 900-923 и в среднем равна 910,4\%. Приведенные данные согласуются с результатами аффринажа золота, добытого в 2002 г. на прилегающем участке месторождения. По итогам аффиннажных работ, выполнявшихся в 2002 г. на аффиннажном заводе, шлиховая пробность на отработанном Восточном участке исследуемой россыпи составила в среднем 893,7\%, лигатурная - 908,7\%.

Ключевые слова: россыпь, фракция, россыпеобразующие формации, крупность золота, гранулометрический состав, афффинаж, пробность, шлих.

Для цитирования: Босиков И. И., Клюев Р. В., Темиров К. В., Мазко А. И. Комплексная оценка параметров и закономерностей распределения благородных металлов влияющих на их продуктивность. Геология и геосииика Юга России. 2021. 11 (3): 115 - 128. DOI: 10.46698/NNC.2021.99.14.010. 
Original paper

\title{
Comprehensive assessment of parameters and regularities of the distribution of precious metals affecting their productivity
}

\author{
I. I. Bosikov ${ }^{(D}$ 1, R. R. Klyuev ${ }^{(12}$, K. V. Temirov ${ }^{(D 3}$, A. I. Mazko ${ }^{(D 1}$ \\ ${ }^{1}$ North Caucasian institute of Mining and Metallurgy (State Technological University), 44 \\ Nikolaeva Str., Vladikavkaz 362021, Russian Federation; \\ ${ }^{2}$ Moscow Polytechnic University, 38 Bolshaya Semenovskaya Str., Moscow 107203, Russian \\ Federation, e-mail: kluev-roman@ rambler.ru; \\ ${ }^{3}$ Department for ensuring the implementation of national projects in the Republic of North \\ Ossetia-Alania (Project Office of the Republic of North Ossetia-Alania), 2 Lenina Square, \\ Vladikavkaz 362040, Russian Federation
}

Reseived: 06.08.2021, revised: 21.08.2021, accepted: 03.09.2021

\begin{abstract}
Relevance. Over the past decades, since the sixties of the twentieth century, the production of precious metals has steadily increased by $12 \%$ per year. Moreover, demand outstrips supply. This is partly due to the fact that noble metals are the equivalent of the value of human labor, and on the other hand, their industrial use is increasing, based on the properties of elements of this group of metals. Aim. To analyze and comprehensively assess the parameters and patterns of distribution of noble metals (NM) affecting their productivity. Methods. Mineralogical and petrographic analysis of concentrates from wells, assay analysis of gold from exploration wells, facies and formation analysis, and particle size analysis were carried out. Results. The size of gold in primary deposits has a direct and decisive influence on the productivity of placers formed by them: the finer the gold, the lower the productivity. This is explained by the fact that small and submicroscopic gold grains have a high migration capacity in the water-alluvial environment, such gold will not form large alluvial deposits. According to the results of assay analyzes of gold from exploration wells, the average placer fineness of the metal within the area of this reserve calculation is $890.1 \%$ and fluctuates mainly in the range of $889-898$, in one case it decreases to 840 (line 24). The ligature fineness varies insignificantly, within $900-923$ and is on average $910.4 \%$. These data are consistent with the results of the refining of gold mined in 2002 in the adjacent area of the deposit. According to the results of the refining works carried out in 2002 at the refinery, the placer fineness in the worked out Vostochny area of the studied placer averaged $893.7 \%$, the ligature fineness $-908.7 \%$.
\end{abstract}

Keywords: placer, fraction, placer-forming formations, gold size, granulometric composition, refining, fineness, concentrate.

For citation: Bosikov I.I., Klyuev R. V., Temirov K. V., Mazko A. I. Comprehensive assessment of parameters and regularities of the distribution of precious metals affecting their productivity. Geologiya I Geofizika Yuga Rossii = Geology and Geophysics of Russian South. (in Russ.). 2021. 11 (3): 115 - 128. DOl: 10.46698/ VNC.2021.99.14.010.

\section{Введение}

Исследования проводились на золотоносном россыпном месторождении [Hекрасов, 2018]. Для наблюдения изменения размеров и характера распределения золотой фракции были использованы материалы ранее проводимых работ на участке [Босиков и др., 2021а, б; Клюев и др., 2020]. 
Крупность золота. Данный показатель является наиболее важным и предопределяет продуктивность россыпеобразующих формаций [Некрасов, 2019]. К сожалению, точные количественные характеристики крупности золота из различных типов руд до сих пор отсутствуют, что объясняется несовершенством, сложностью и высокой стоимостью методов определения гранулометрического состава золота в рудах [Федорова, и др., 2018; Литвиненко, 2018; Шарафелдин, 2018; Nassani et al., 2021; Голик и др., 2020; Чотчаев и др, 2021]. Это обстоятельство заставило проводить сравнительное изучение крупности золота в различных рудах путем анализа отдельных фракций измельченной руды [Song et al., 2017; Tyulenev et. al., 2016, 2018: Zhukovskiy et al., 2019]. Такой подход оправдан, поскольку размер обломков указывает на относительный размер находящихся в них золотин, а ошибка, особенно в мелких классах, более или менее постоянна для всех типов руд [Ganapathy et al., 2020; Sebutsoe et al., 2017; Sinclair et al., 2015].

Крупность золота в коренных месторождениях оказывает прямое и решающее влияние на продуктивность образованных ими россыпей: чем мельче золото, тем ниже продуктивность. Объясняется это, тем что, мелкие и субмикроскопические зерна золота обладают большой миграционной способностью в водно-аллювиальной среде, такое золото не будет образовывать крупных россыпных месторождений.

\section{Методы исследований}

При проведении исследований были применены: минералого-петрографический анализ шлихов из скважин; пробирный анализ золота из разведочных скважин; фациальный и формационный анализ; гранулометрический анализ.

\section{Характеристика золота на россыпном месторожАении}

По данным минералогического изучения шлихов из скважин, все участки россыпного месторождения характеризуются практически однотипным золотом около 90-95\% золота представлено утолщенными пластинками удлиненной, реже округлой формы с плавноизвилистыми, иногда с заливообразными, зазубренными и щелевидными очертаниями боковых сторон (рис. 1).

От 5 до 10\% золота представлено зернами удлиненно-комковидной, округлой, реже палочкообразной формы с неровной поверхностью (рис. 2, 3). Наблюдается увеличение количества золотин в виде зерен во фракциях менее 0,5 мм.

Цвет золота желтый и насыщенно желтый, в некоторых выделениях отмечается слабый зеленоватый оттенок.

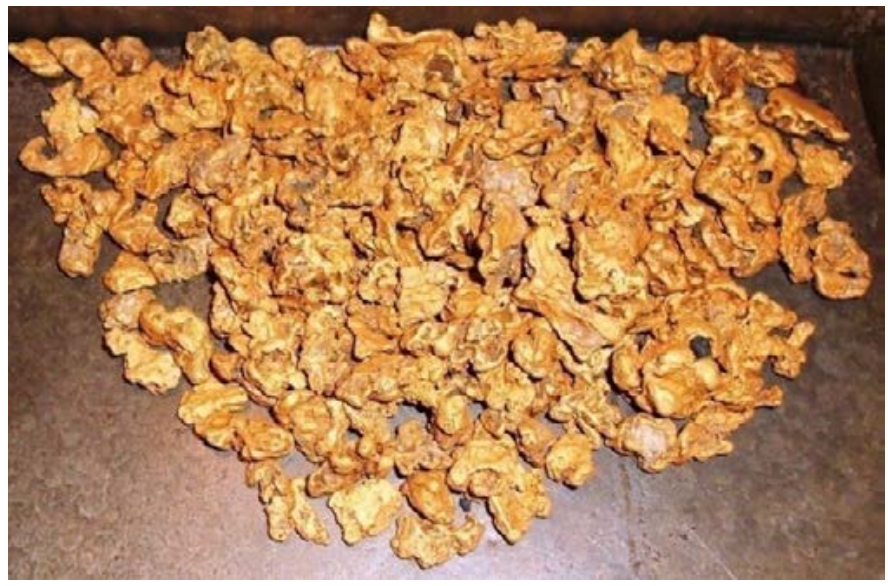

Рис. 1. Разновидности форм самородного золота /

Fig. 1. Varieties of forms of native gold 
Таблиияа 1 / Table 1

Характеристика гранулометрического состава и пробности золота изучаемой россыпи по данным скважин /

Characteristics of the granulometric composition and fineness of gold in the studied placer according to well data

\begin{tabular}{|c|c|c|c|c|c|c|c|c|c|c|c|c|}
\hline \multirow{3}{*}{$\begin{array}{c}\text { №№ } \\
\text { буровых } \\
\text { линий / } \\
\text { №№ of line } \\
\text { drilling }\end{array}$} & \multirow{3}{*}{$\begin{array}{l}\text { №№ } \\
\text { скважин } \\
\text { / №№o of } \\
\text { wells }\end{array}$} & \multicolumn{8}{|c|}{$\begin{array}{c}\text { Гранулометрический состав золота (в \%) по классам и фракциям } \\
\text { крупности (мм) / Grain-size composition of gold (in \%) according to } \\
\text { classes and size division (mm) }\end{array}$} & \multirow{3}{*}{$\begin{array}{c}\text { Сред. } \\
\text { круп- } \\
\text { ность, мм } \\
\text { / Average } \\
\text { grain size }\end{array}$} & \multicolumn{2}{|c|}{$\begin{array}{c}\text { Пробность / } \\
\text { Fineness }\end{array}$} \\
\hline & & \multirow{2}{*}{$\begin{array}{l}\text { Tонкое } \\
\text { / Fine } \\
-0,15\end{array}$} & \multicolumn{2}{|c|}{$\begin{array}{c}\text { Весьма мелкое } \\
\text { / Very small }\end{array}$} & \multicolumn{2}{|c|}{ Мелкое / Small } & \multicolumn{2}{|c|}{$\begin{array}{c}\text { Cреднеe / } \\
\text { Average } \\
\end{array}$} & \multirow{2}{*}{$\begin{array}{c}\text { Kрупное / } \\
\text { Coarse }\end{array}$} & & \multirow{2}{*}{$\begin{array}{l}\text { Шли- } \\
\text { ховая / } \\
\text { Placer }\end{array}$} & \multirow{2}{*}{$\begin{array}{l}\text { Лига- } \\
\text { турная } \\
\text { Base }\end{array}$} \\
\hline & & & $+0,15$ & $+0,25$ & $+0,5$ & $+1,0$ & $+2,0$ & $+3,0$ & & & & \\
\hline \multirow[t]{2}{*}{6} & \multirow[t]{2}{*}{$5-15$} & 1,9 & 3,5 & 18,2 & 27,5 & 48,9 & 0,0 & 0,0 & 0,0 & \multirow[t]{2}{*}{0,98} & \multirow[t]{2}{*}{897} & \multirow[t]{2}{*}{914} \\
\hline & & 1,9 & \multicolumn{2}{|c|}{21,7} & \multicolumn{2}{|c|}{76,4} & \multicolumn{2}{|c|}{0} & 0 & & & \\
\hline \multirow[t]{2}{*}{8} & \multirow[t]{2}{*}{$6-20$} & 0,8 & 5,9 & 10,4 & 35,5 & 47,3 & 0,0 & 0,0 & 0,0 & \multirow[t]{2}{*}{0,95} & \multirow[t]{2}{*}{886} & \multirow[t]{2}{*}{911} \\
\hline & & 0,8 & \multicolumn{2}{|c|}{16,3} & & & ( & & 0 & & & \\
\hline 10 & $2-16$ & 1,1 & 2,0 & 9,9 & 33,6 & 40,3 & 13,1 & 0,0 & 0,0 & 1,08 & 899 & 903 \\
\hline & & 1,1 & & & & & ( & & 0 & & & \\
\hline 11 & $1-15$ & 0,2 & 8,8 & 16,0 & 20,8 & 22,0 & 18,3 & 13,9 & 0,0 & 1,19 & 893 & 914 \\
\hline & & 0,2 & & & & & 32 & & 0 & & & \\
\hline 12 & $7-17$ & 1,2 & 3,2 & 10,8 & 24,7 & 25,3 & 15,1 & 19,7 & 0,0 & 1,40 & 896 & 900 \\
\hline & & 1,2 & & & & & 34 & & 0 & & & \\
\hline 13 & $1-16$ & 0,7 & 2,7 & 6,9 & 21,0 & 19,8 & 20,8 & 11,9 & 16,2 & 1,95 & 890 & 908 \\
\hline & & 0,7 & & & & & 32 & & 16,2 & & & \\
\hline 14 & $1-15$ & 2,7 & 1,5 & 14,9 & 23,1 & 12,8 & 32,8 & 12,2 & 0,0 & 1,61 & 898 & 906 \\
\hline & & 2,7 & & & & & 45 & & 0 & & & \\
\hline 15 & $5-19$ & 1,0 & 4,7 & 10,4 & 25,1 & 22,8 & 11,9 & 24,1 & 0,0 & 1,39 & 889 & 902 \\
\hline & & 1,0 & & & & & 36 & & 0 & & & \\
\hline 18 & $1-20$ & 3,5 & 2,5 & 9,8 & 28,2 & 25,7 & 20,5 & 9,8 & 0,0 & 1,23 & 897 & 915 \\
\hline & & 3,5 & & & & & 30 & & 0 & & & \\
\hline 20 & $0-14$ & 0,6 & 2,2 & 7,9 & 22,7 & 21,3 & 30,0 & 15,3 & 0,0 & 1,78 & 890 & 906 \\
\hline & & 0,6 & & & & & 45 & & 0 & & & \\
\hline 22 & $3-16$ & 1,0 & 3,3 & 9,3 & 33,7 & 43,4 & 9,3 & 0,0 & 0,0 & 1,06 & 892 & 923 \\
\hline & & 1,0 & & & & & 9 & & & & & \\
\hline 24 & $2-17$ & 0,9 & 4,2 & 11,9 & 20,7 & 16,5 & 20,8 & 10,9 & 14,1 & 1,75 & 840 & 922 \\
\hline & & 0,9 & & & & & 31 & & 14,1 & & & \\
\hline 25 & $0-14$ & 0,3 & 2,4 & 15,7 & 19,5 & 18,5 & 17,2 & 13,5 & 12,8 & 1,65 & 898 & 910 \\
\hline & & 0,3 & & & & & 30 & & 12,8 & & & \\
\hline 26 & $0-15$ & 1,3 & 3,5 & 11,3 & 26,5 & 15,2 & 26,6 & 15,6 & 0,0 & 1,49 & 897 & 912 \\
\hline & & 1,3 & & & & & 42 & & 0 & & & \\
\hline $\mathrm{C}_{\mathrm{n}}$ & $y=$ & 1,1 & 3,5 & 11,3 & 25,1 & 25,3 & 18,0 & 11,2 & 4,5 & 126 & - & 0104 \\
\hline Средние & Average & 1,1 & & & & & 29 & & 4,5 & 1,50 & 090,1 & 910,4 \\
\hline
\end{tabular}




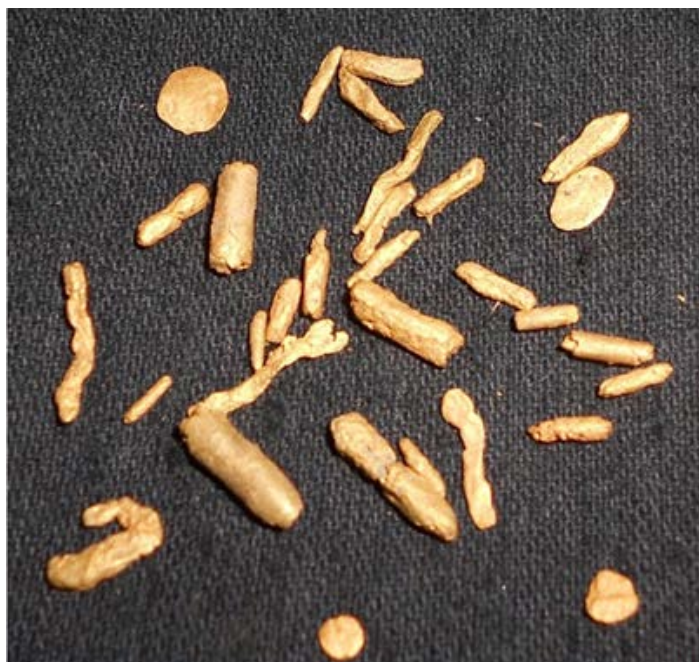

Рис. 2. Палочкообразная и округлая форма I Fig. 2. Rod-shaped and rounded shape

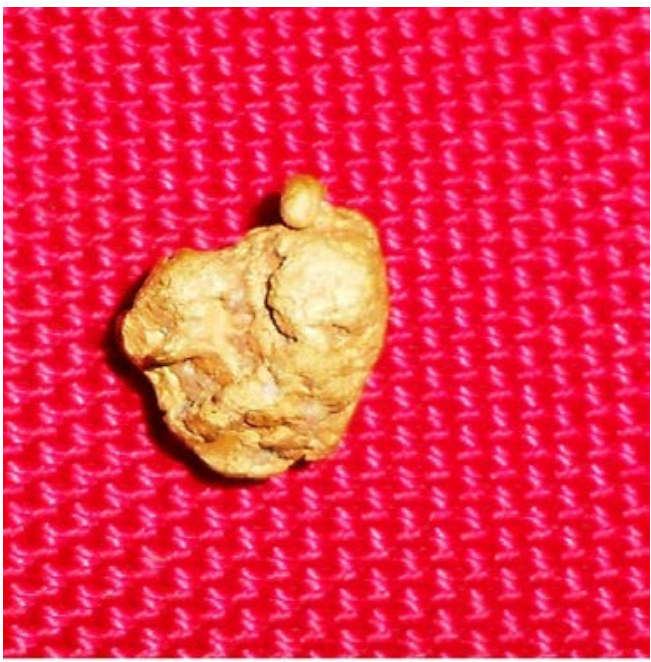

Рис. 3. Комковатая форма I Fig. 3. Lumpy shape

Окатанность золота в основном средняя (70-80\%), реже хорошая (20-30\%).

Гранулометрический состав и пробность золота из скважин приведены в таблице 1.

\section{Результаты работы и их обсужАение.}

Крупность золота в коренных месторождениях оказывает прямое и решающее влияние на продуктивность образованных ими россыпей: чем мельче золото, тем ниже продуктивность. Объясняется это, тем что, мелкие и субмикроскопические зерна золота обладают большой миграционной способностью в водно-аллювиальной среде, такое золото не будет образовывать крупных россыпных месторождений.

Согласно приведенной таблице, в разведанной части россыпи резко преобладает золото мелкой $(50,4 \%)$ и средней $(29,2 \%)$ фракций (рис. 4). Характерно также повышенное содержание весьма мелкой фракции (14,8\%). Количество тонкого и крупного золота невелико (соответственно 1,1 и 4,5\%).

Крупность золота по линиям меняется от 0,95-1,08 мм (линии $6,8,10,22$ ) до 1,65-1,95 мм (линии 13, 20, 24, 25). В целом, крупность металла (рис. 5) возрастает на участках с более высокими значениями содержания и линейного запаса золота и заметно снижается к хвостовой части россыпи. Средний размер выделений золота, подсчитанный по формуле Островского, составляет 1,36 мм.
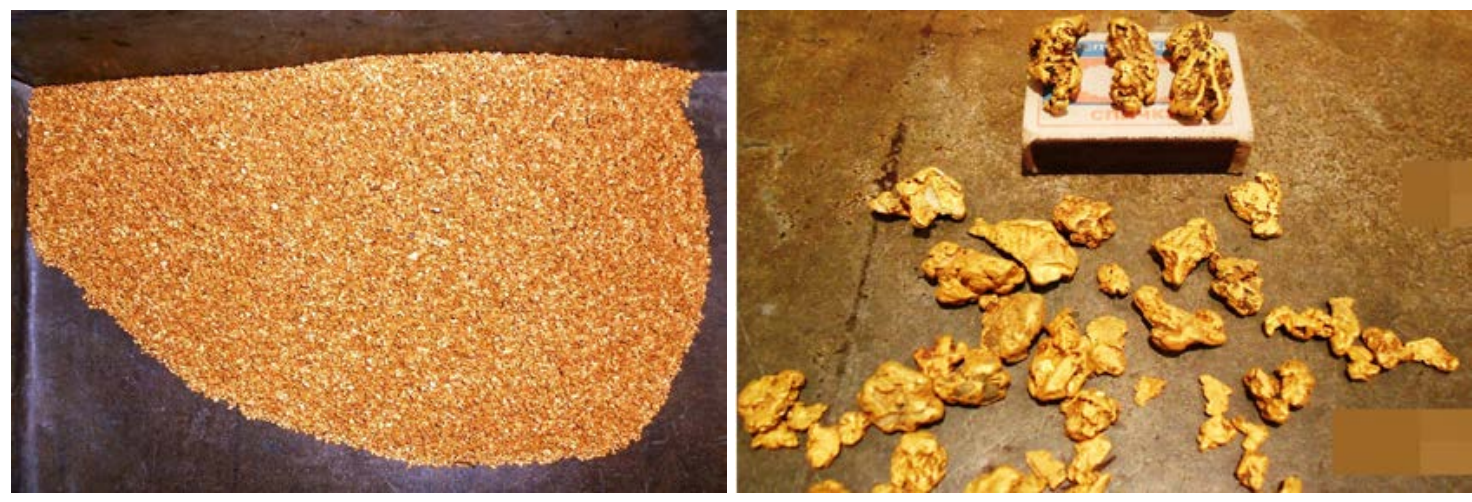

Рис. 4. Мелкая и средняя фракции / Рис. 5. Крупная фракция /

Fig. 4. Small and medium fractions Fig. 5. Large fraction 
Таблица 2 / Table 2

Характеристика распределения фракций крупности золота в продольном направлении россыпи по разведочным линиям скважин /

Characteristics of the distribution of fractions of the size of gold in the longitudinal direction of the placer along the exploration lines of wells

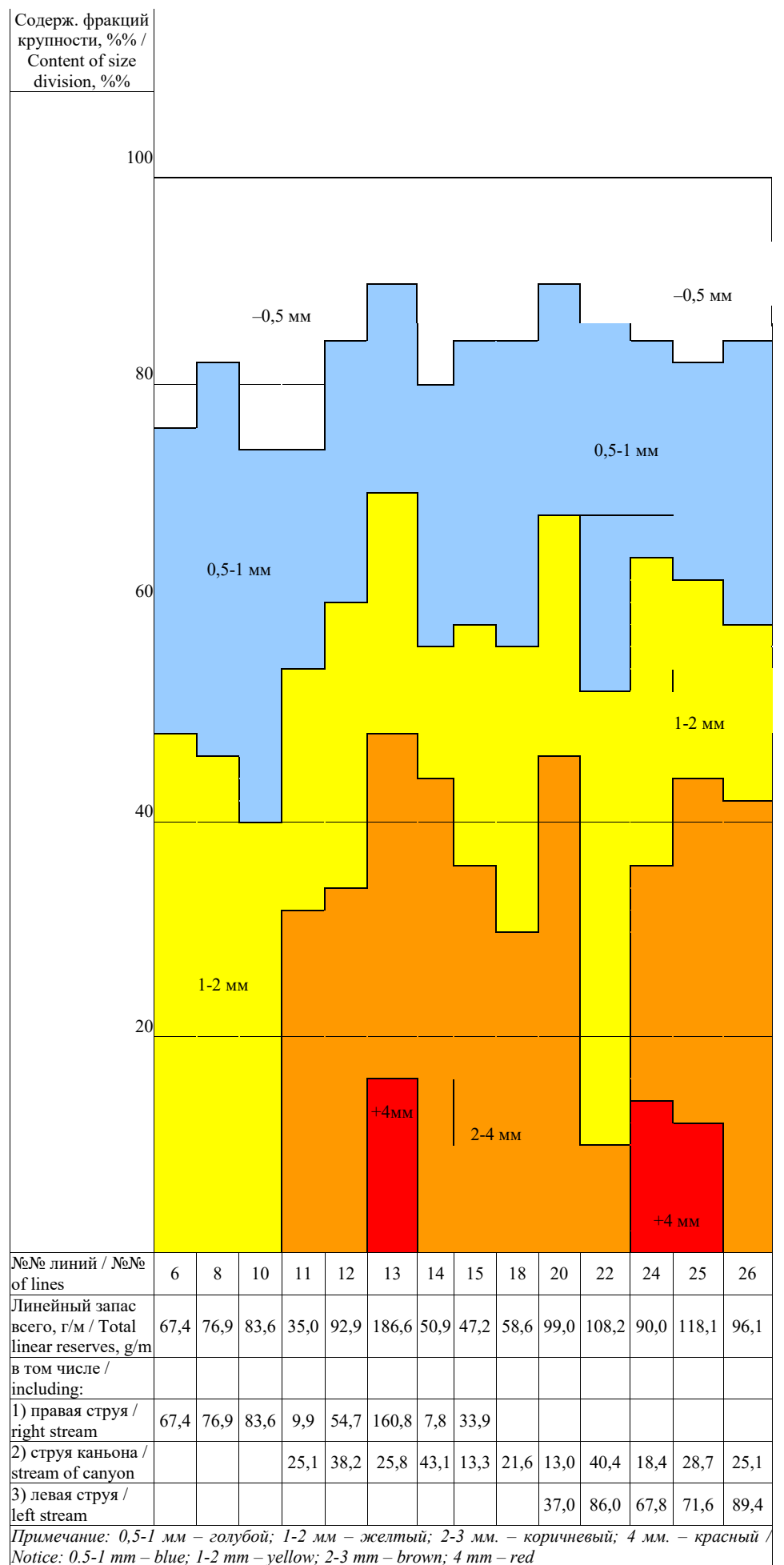


Таблиияа 3 / Table 3

Сравнительная характеристика распределения линейных запасов, средней крупности и пробности золота россыпи по разведочным линиям скважин /

Comparative characteristics of the distribution of linear reserves, average size and fineness of placer gold along exploration lines of wells

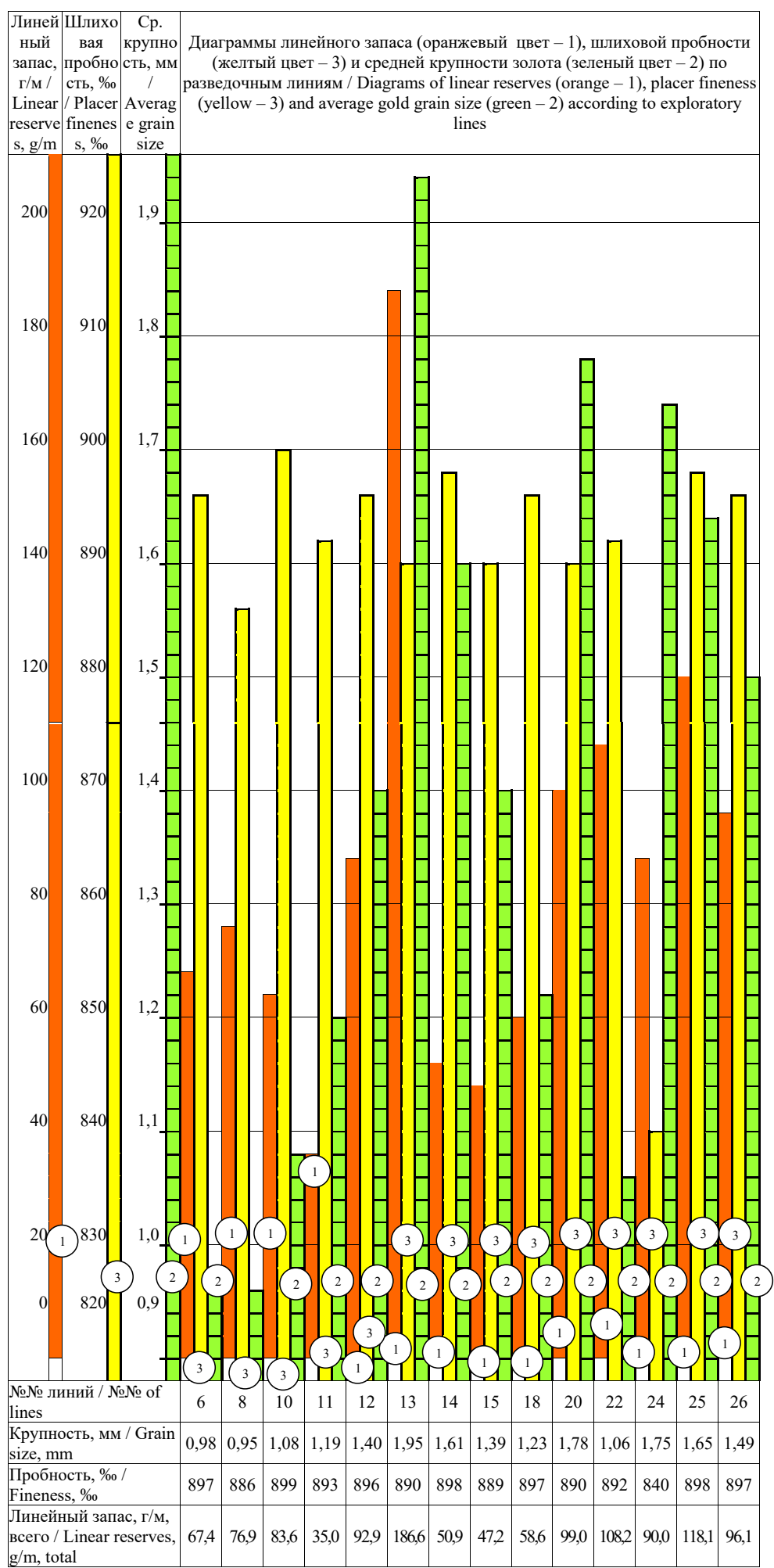


Характеристика распределения фракций крупности золота в продольном направлении россыпи приведена в таблице 2 .

По результатам пробирных анализов золота из разведочных скважин, средняя шлиховая пробность металла в пределах площади данного подсчета запасов составляет $890,1 \%$ и колеблется в основном в диапазоне 889-898, в одном случае понижается до 840 (линия 24). Лигатурная пробность меняется незначительно, в пределах 900-923 и в среднем равна 910,4\%.

Приведенные данные согласуются с результатами аффинажа золота, добытого в 2002 г. на прилегающем участке месторождения. По итогам аффинажных работ, выполнявшихся в 2002 г. на аффинажном заводе, шлиховая пробность на отработанном Восточном участке исследуемой россыпи составила в среднем $893,7 \%$, лигатурная - 908,7\%о.

Главной лигатурной примесью в самородном золоте является серебро (ценный попутный компонент III группы); весовое отношение Au / Ag составляет 1/0,095.

Сравнительная характеристика распределения линейных запасов, средней крупности и пробности золота по разведочным линиям приведена в таблице 3.

Минералого-петрографический анализ. Минеральный состав россыпи - золото, серебро, пирит, лимонит, магнетит, гранат, кварц.

Золото Аu (рис. 6). Один из самых высокоотражающих минералов; цвет насыщенный желтый (р 48\%); внутренних рефлексов нет, но в скрещенных николях отчетливо видны все царапины. В контакте с выделениями золота больших размеров пирит и галенит имеют серый оттенок, а халькопирит выглядит серо-зеленоватым. Золото видимое отмечается повсеместно в местах его повышенного содержания во всех эксплуатируемых жилах. Форма крупных золотин самая различная [Augustin et al., 2018; Luo et al., 2018]. Это пористые изометричные, палочкообразные, неправильной формы зерна, включенные в кварц или располагающиеся по контактам рудных минералов. И преобладающие величины видимых золотин составляют доли мм, максимальные - 2-3 мм. Реже встречаются скопления золотин неправильной формы в кварце и в контактах пирита и тетрадимита с кварцем. В аншлифах самородное золото наблюдается часто, обычно в срастании с тетрадимитом, пирротином, галенитом, халькопиритом, блеклой рудой, а также в виде изометричных включений на границах зерен кварца и рудных минералов. Размер золотин от 0,005 мм до 0,1 мм. Формы различны: палочки длиной 0,3-0,4 мм или пластинки в хлорите по спайности, иногда цемент дробленных зерен арсенопирита или просто

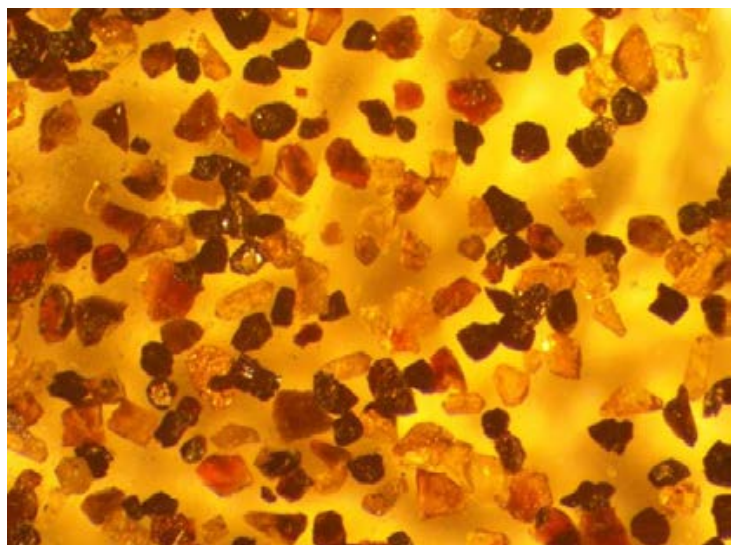

Рис. 6. Золото в илихе общзий /

Fig. 6. Gold in concentrate common изометричные выделения в халькопирите и блеклой руде.

Золото в единичных зернах встречается в шлихах сравнительно часто в областях развития гранитоидов. Вблизи от коренных источников оно имеет деидритовидную, губчатую, почковидную, пластинчатую форму. При небольшом переносе зерна становятся округлыми, расплющенными или скрученными, с мелкобугорчатой поверхностью. Повышенную миграционную способность «имеет «носовое» золото 


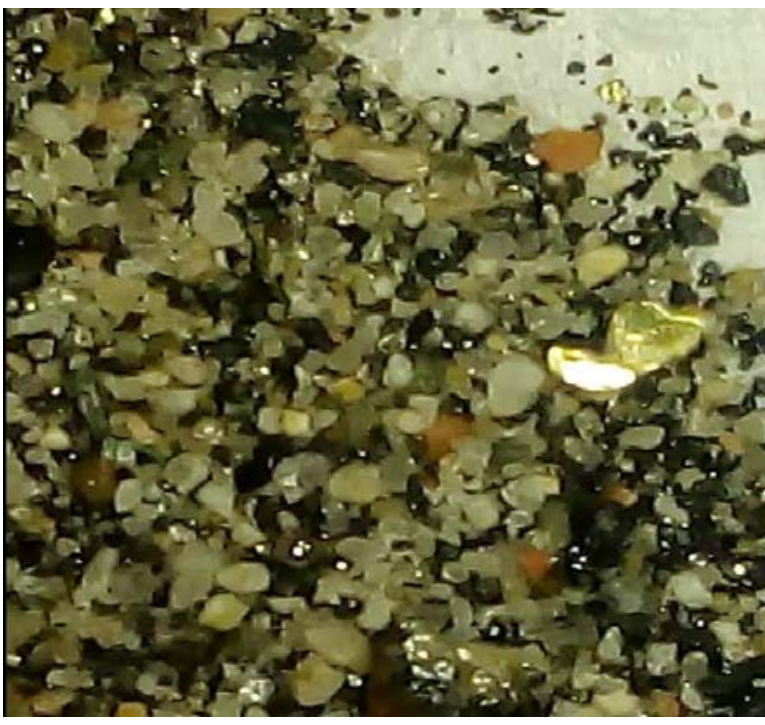

Puc. 7. Серебро /

Fig. 7. Silver
- листочки или чешуйки округлой формы, нередко выпукло-вогнутые, размером менее 1 мм в поперечнике. Очень мелкие зерна (менее 0,1 мм) могут быть и изометричными.

Серебро Ag (рис. 7). Содержит примеси $\mathrm{Au}, \mathrm{Cu}, \mathrm{Sb}$. Сингония кубическая. Неправильные древовидные или пластинчатые зёрна, сплющенные чешуйки. Поверхность зёрен неровная, ямчатая, иногда покрыта чёрным налетом. Цвет серебряно-белый, серый, блеск металлический. Спайность отсутствует, излом крючковатый. Ковкое и тягучее. Плотность 10,1-11,1, твёрдость 2,5-3.

Правильные кристаллы редки. Характерны дендриты, проволочные и волокнистые формы. Часто бывает зернистое до тонконитевидного, также в виде пластинок или сплющенных чешуек. Уд. вес 10-11. Весьма ковко и тягуче. Непрозрачно. Под микроскопом в отраженном свете кремово-белое с сильным блеском. Полируется хорошо. Изотропно. $\mathrm{C} \mathrm{HNO}_{3}$ вскипает. После травления этой кислотой поверхность становится шероховатой; от $\mathrm{HCl}$ оно слегка тускнеет.

В россыпях обычно неустойчиво и переходит в серебряный блеск или кераргирит. При дроблении расплющивается в неправильные пластинки и чешуйки с крючковатым изломом.

Самородное серебро состоит из неправильной формы зерен, пластинок, чешуек, иногда проволочной или нитевидной.

Магнетит $\mathbf{F e O} \cdot \mathbf{F e}_{2} \mathbf{O}_{3}$ (рис. 8). Минерал магнитной фракции. Его октаэдрические кристаллы имеют острые ребра, ступенчатые фигуры роста на гранях, иногда скелетные формы. Обычно представляет собой изометричные зерна, остроугольные обломки. Хорошо окатанные зерна магнетита, особенно мелкие, редки.

В магнитной фракции присутствуют неполные псевдоморфозы гематита по магнетиту (мартит), оолиты и стяжения красного железняка, частично или полностью восстановившиеся до магнетита. Цвет магнетита черный, на поверхности появляются пленки бурого цвета. Раздавливается минерал с трудом, излом неровный, порошок черный. В самой фракции зерна магнетита также стягиваются в цепочки, агрегируются, притягиваются друг к другу и к стальной игле.

Пирит $\mathrm{FeS}_{2}$ (рис. 9). Наиболее, распространенный в шлихах сульфид, часто встречающийся в виде

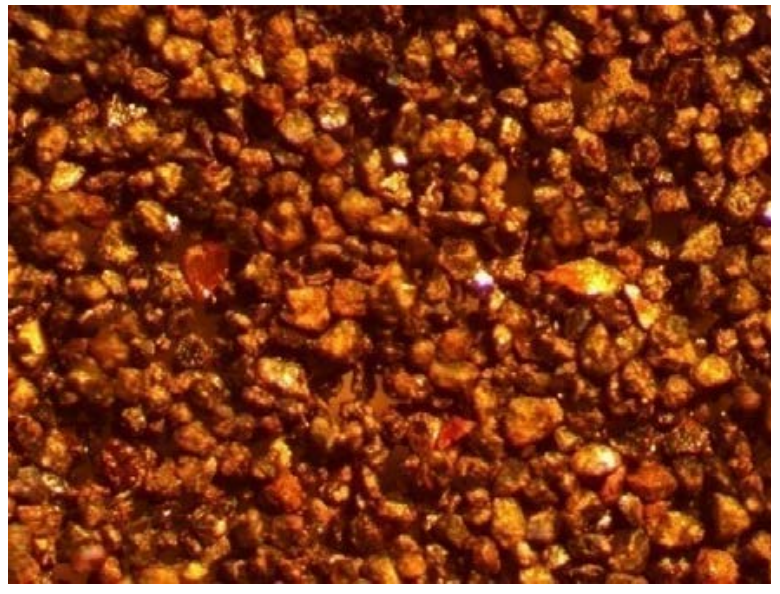

Puc. 8. Магнетит / Fig. 8. Magnetite 
кристаллов, их обломков или срастаний, реже он образует остроугольные зерна.

В некоторых кварцево-золотоносных жилах октаэдры пирита приурочены к верхним частям жильных тел. При окислении пирит покрывается черными, коричневыми или бурыми пленками оксидов и гидроокислов железа. Такой пирит внешне похож на перовскит, темноокрашенный рутил.

Лимонит $\mathrm{Fe}_{2} \mathrm{O}_{3} \cdot \mathbf{n H}_{2} \mathrm{O}$ (рис. 10). Как смесь гидрооксидов железа, среди которых преобладает гидрогетит,

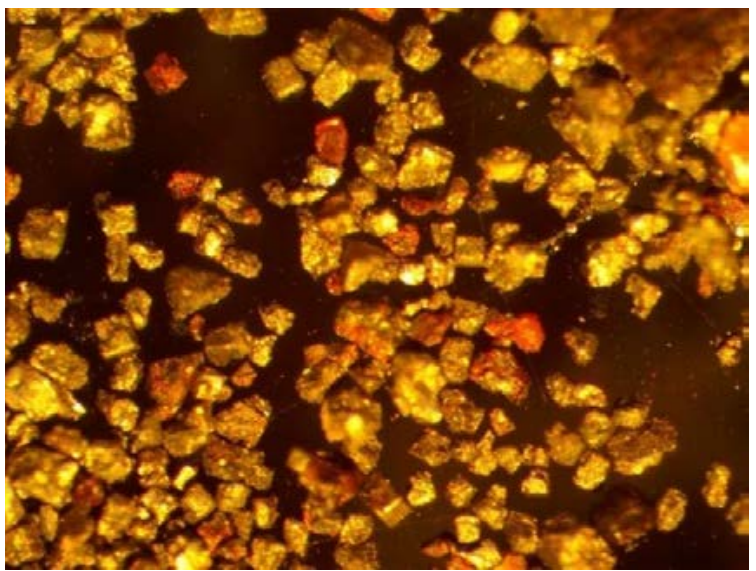

Puc. 9. Пирuт $\mathrm{FeS}_{2} /$

Fig. 9. Pyrite $\mathrm{FeS}_{2}$ морфологически очень разнообразен. Он образует округлые зерна, стяжения, ооли-

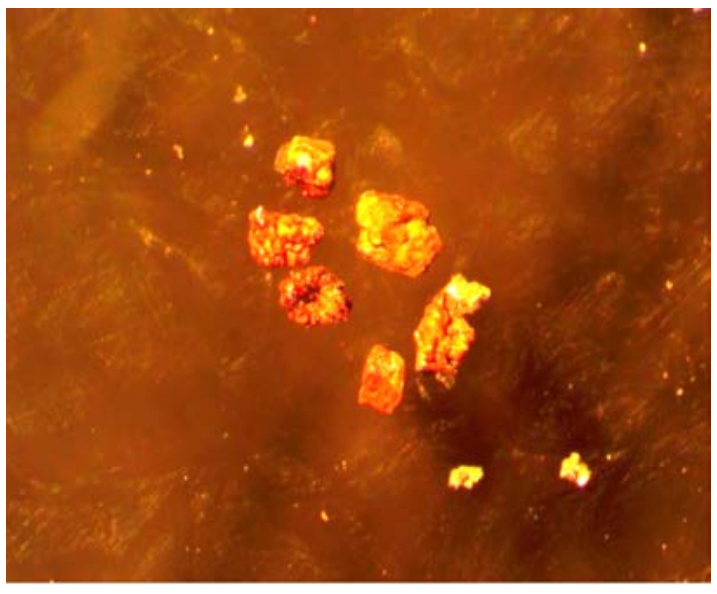

Рис. 10. Лимонит, зерна золота / Fig. 10. Limonite, grains of gold ты, встречается в виде землистых масс и чечевицеобразных скоплений, нередко представляющих собой остатки колоний отмерших железобактерий. Лимонит присутствует в шлихах в виде псевдоморфоз по пириту, сидериту, магнетиту.

В зависимости от минерального состава и агрегатного состояния цвет лимонита меняется от охряно-желтого и бурого до темно-коричневого, почти черного.

Кварц $\mathrm{SiO}_{2}$ (рис. 11). Кварц в россыпях встречается в виде обломков различной формы и размеров, гальки, песка, кристаллов. Кристаллы - гексагональной призмы, увенчанные шестигранной ромбоэдрической головкой с одной стороны, реже с двух. Чаще встречаются удлиненные «обелисковидные» кристаллы, помимо них есть уплощенные кварцевые кристаллы. На гранях призмы наблюдается характерная поперечная штриховка. Кристаллы имеют стеклянный блеск, преимущественно прозрачные.

Различной окраски - бесцветные, дымчатые, практически черные и молочно белые. Разновидности кварца на участке: горный хрусталь - бесцветного прозрачного цвета, встречается часто, средний размер кристаллов 1,5 см, раухтопаз - дымчатый кварц, светло-серого цвета. В россыпи представлен обломками размерами от нескольких миллиметров до нескольких сантиметров.

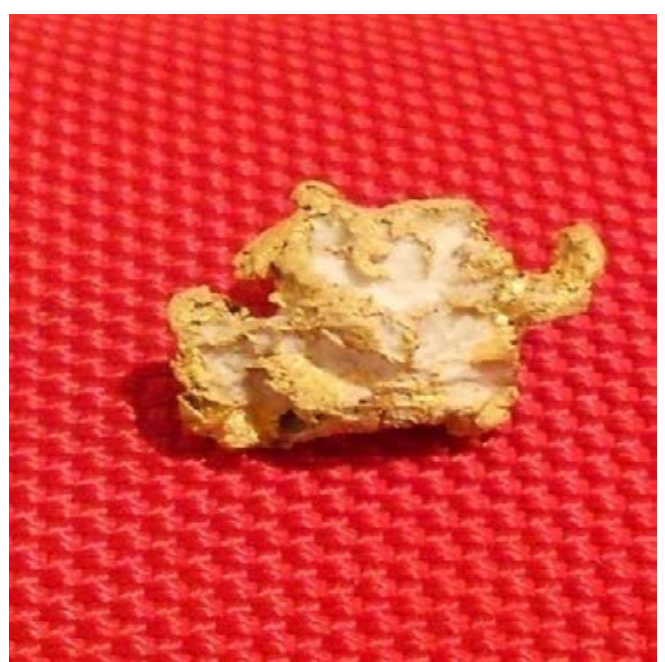

Рис. 11. Золотой сросток с кварием / Fig. 11. Gold splice with quartz 


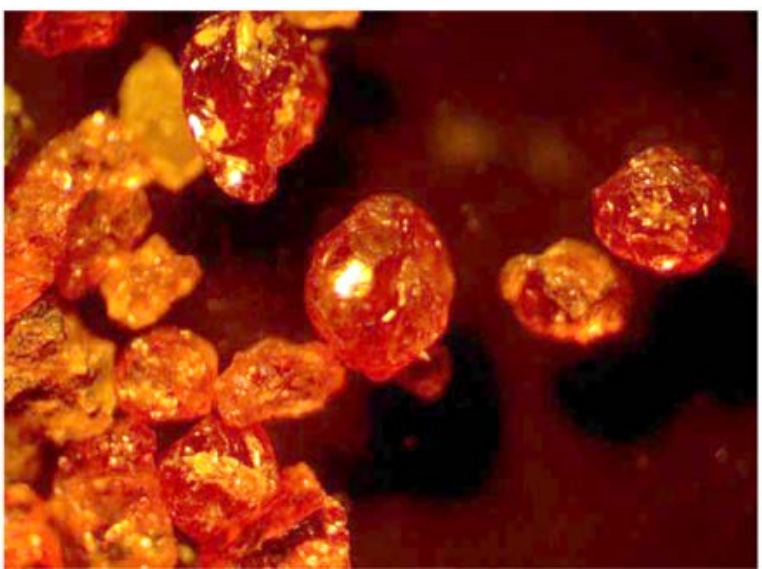

Puc. 12. Гранат $\mathrm{Fe}_{3} \mathrm{Al}_{2}\left[\mathrm{SiO}_{4}\right]_{3} /$

Fig. 12. Garnet $\mathrm{Fe}_{3} \mathrm{Al}_{2}\left[\mathrm{SiO}_{4}\right]_{3}$

Хорошо виден раковистый излом, кремень - тонкозернистый скрытокристаллический агрегат. Был обнаружен на поверхности коры выветривания в виде гальки. Размеры 75 см. Внешне окрашен в коричневые цвета, внутри темнее - темно-серый.

Гранат $\mathrm{Fe}_{3} \mathrm{Al}_{2}\left[\mathrm{SiO}_{4}\right]_{3}$ (рис. 12). Особенно близок по составу к альмандину, встречается во многих шлихах, особенно в областях развития метаморфических толщ и распространения ледниковых отложений.

Гранат встречается в виде изометричных кристаллов, угловатых обломков с неровными изломом и, реже, корродированных или окатанных зерен с шероховатой поверхностью. Кристаллы и угловатые зерна гранатов, преимущественно альмандина, узнаются без затруднений. Окатанные зерна похожи на циркон, у которого высокое двупреломление.

\section{ВывОАЫ}

По приведенным выше таблицам (2 и 3 ) можно сказать, что никакой закономерности распределения по крупности либо пробности металла на россыпном месторождении нет. А судя по характеристикам данное месторождение является весьма продуктивным.

По результатам пробирных анализов золота из разведочных скважин, средняя шлиховая пробность металла в пределах площади данного подсчета запасов составляет $890,1 \%$ и колеблется в основном в диапазоне $889-898$, в одном случае понижается до 840 (линия 24). Лигатурная пробность меняется незначительно, в пределах 900-923 и в среднем равна 910,4\%.

Приведенные данные согласуются с результатами аффинажа золота, добытого в 2009 г. на прилегающем участке месторождения. По итогам аффинажных работ, выполнявшихся в 2019 г. на аффинажном заводе, шлиховая пробность на отработанном Восточном участке россыпи составила в среднем 893,7\%о, лигатурная 908,7\% .

Главной лигатурной примесью в самородном золоте является серебро (ценный попутный компонент III группы); весовое отношение $\mathrm{Au} / \mathrm{Ag}$ составляет 1/0,095.

\section{Аитература}

1. Босиков И.И., Клюев Р.В., Гаврина О.А. Анализ геолого-геофизических материалов и качественная оценка перспектив нефтегазоносности Южно-Харбижинского участка (Северный Кавказ). // Геология и геофизика Юга России. - 2021 a. - № 11 (1). - С. 6-21. DOI: 10.46698/VNC.2021.36.47.001.

2. Босиков И. И., Клюев Р. В., Хетагуров В. Н., Ажмухамедов И. М. Разработка методов и средств управления аэрогазодинамическими процессами на добычных участках. // Устойчивое развитие горных территорий. - 2021б. - № 1. - C. 77-83. DOI: 10.21177/1998-45022021-13-1-77-83. 
3. Голик В.И., Бурдзиева О.Г., Дзеранов Б. В. Управление геодинамикой массива путем регулирования величины напряжений. // Геология и геофизика Юга России. -2020 . № 10 (2). - C. 147-160. DOI: 10.46698/VNC.2020.93.21.011.

4. Клюев Р.В., Босиков И.И., Майер А.В., Гаврина О. А. Комплексный анализ применения эффективных технологий для повышения устойчивого развития природно-технической системы. // Устойчивое развитие горных территорий. - 2020. - №2. - С. 283-290. DOI: 10.21177/1998-4502-2020-12-2-283-290.

5. Литвиненко И. С. О коренных источниках россыпей юглеровского рудно-россыпного поля (Северо-Восток России). // Разведка и охрана недр. - 2018. - № 6. - С. 3-10.

6. Некрасов Е. М. Локализация руд золота в разломах разных типов. // Известия высших учебных заведений. Геология и разведка. - 2019. - № 6. - С. 33-43.

7. Некрасов Е. М. Поиск «слепых» золоторудных тел жильного типа. // Руды и металлы. - 2018. - №3. - С. 55-71. DOI: 10.24411/0869-5997-2018-10007.

8. Федорова Л. Л., Куляндин Г. А. Опыт применения метода георадиолокации при эксплуатационной разведке россыпных месторождений золота Якутии. // Успехи современного естествознания. - 2018. - № 11. - С. 160-165.

9. Чотчаев Х. О., Бурдзиева О.Г., Заалишвили В.Б. Зонирование высокогорных территорий по геоэкологическим нагрузкам, обусловленным геодинамическими и климатическими воздействиями. // Геология и геофизика Юга России. - 2021. - № 11 (1) - С. 81-94. DOI: 10.46698/VNC.2021.15.66.007.

10. Шарафелдин Х.Э. Позднеорогенные месторождения золота Египта. // Горные науки и технологии. - 2018. - № 1. - С. 89-96. DOI: 10.17073/2500-0632-2018-1-89-96.

11. Augustin J., Gaboury D. Multi-stage and multi-sourced fluid and gold in the formation of orogenic gold deposits in the world-class Mana district of Burkina Faso - Revealed by LAICP-MS analysis of pyrites and arsenopyrites. // Ore Geology Reviews. - 2018. - Vol. 104. - pp. 495-521. DOI: 0.1016/j. oregeorev. 2018.11.011.

12. Ganapathy G.P., Zaalishvili V.B., Chandrasekaran S.S., Melkov, D.A. Integrated monitoring of slope process in India and Russia. // Sustainable Development of Mountain Territories. - 2020. - No. 12 (4). - pp. 572-581. DOI: 10.21177/1998-4502-2020-12-4-572-581.

13. Luo D., Zeng G. Application and effects of singularity analysis in evaluating the denudation degree of Carlin-type gold deposits in southwest Guizhou, China. // Ore Geology Reviews - 2018. - Vol. 96. - pp. 164-180. DOI: 10.1016/j. oregeorev. 2018.04.018.

14. Nassani A.A., Aldakhil A. M., Zaman K. Ecological footprints jeopardy for mineral resource extraction: Efficient use of energy, financial development and insurance services to conserve natural resources // Resources Policy. - 2021. - Vol. 74. - №. 102271. DOI: 10.1016/j. resourpol. 2021.102271.

15. Sebutsoe T.C., Musingwini C. Characterizing a mining production system for decisionmaking purposes in a platinum mine. // The Journal of the Southern African Institute of Mining and Metallurgy. - 2017. - Vol. 117. - pp. 199-206.

16. Sinclair L., Thompson J. In situ leaching of copper: Challenges and future prospects. // Hydrometallurgy. - 2015. - Vol. 157. - pp. 306-324. DOI: 10.1016/j. hydromet. 2015.08.022.

17. Song X., Pettersen J.B., Pedersen K.B., Roberg S. Comparative life cycle assessment of tailings management and energy scenarios for a copperore mine: A case study in Northern Norway. // Journal of Cleaner Production. - 2017. - Vol. 16415. - pp. 892-904.

18. Tyulenev M.A., Zhironkin S.A., Garina E.A. The method of coal losses reducing at mining by shovels. // International Journal of Mining and Mineral Engineering. - 2016. - No. 7 (4). - pp. 363-370. DOI: 10.1504/IJMME. 2016.079990.

19. Tyulenev M.A., Markov S. O., Gasanov M.A., Zhironkin S.A. Numerical Modeling in the Structural Study of Technogenic Rock Array. // Geotechnical and Geological Engineering. 2018. - No. 36 (5). - pp. 2789-2797. DOI: 10.1007/s10706-018-0501-3. 
20. Zhukovskiy Y., Batueva D., Buldysko A., Shabalov M. Motivation towards energy saving by means of IoT personal energy manager platform. // Journal of Physics: Conference Series. 2019. - No. 1333 (6). DOI: 10.1088/1742-6596/1333/6/062033.

\section{References}

1. Bosikov I. I., Klyuev R. V., Gavrina O.A. Analysis of geological-geophysical materialsand qualitative assessment of the oil and gas perspectives of the Yuzhno-Kharbizhinsky area (Northern Caucasus). Geology and Geophysics of Russian South, 2021a. No. 11 (1). pp. 6-21. DOI:10.46698/ VNC.2021.36.47.001. (In Russ.)

2. Bosikov I.I., Klyuev R.V., Khetagurov V.N., Azhmukhamedov I.M. Development of methods and management tools aerogasdynamics processes at mining sites. Sustainable development of mountain territories, 2021b. No. 1. pp. 77-83. DOI: 10.21177/1998-45022021-13-1-77-83. (In Russ.)

3. Golik V.I., Burdzieva O. G., Dzeranov B. V. Ground geodynamics control by regulating stress level. Geology and Geophysics of Russian South, 2020. No. 10 (2). pp. 147-160. DOI: 10.46698/VNC.2020.93.21.011. (in Russ.)

4. Klyuev R.V., Bosikov I. I., Mayer A.V., Gavrina O.A. Comprehensive analysis of the effective technologies application to increase sustainable development of the natural-technical system. Sustainable Development of Mountain Territories, 2020. No. 2. pp. 283-290. DOI: 10.21177/1998-4502-2020-12-2-283-290. (In Russ.)

5. Litvinenko I. S. Lode sources of placer deposits in yugler mineral area, North-east Russia. Exploration and protection of mineral resources, 2018. No. 6. pp. 3-10. (In Russ.)

6. Nekrasov E. M. Localisation of gold ores in faults of different types. Proceedings of higher educational institutions. Geology and exploration, 2019, No. 1. pp. 33-43. (In Russ.)

7. Nekrasov E. M. Prospecting for lode-type blind gold orebodies. Ores and Metals, 2018. No. 3. pp. 55-71. DOI: 10.24411/0869-5997-2018-10007. (In Russ.)

8. Fedorova L.L., Kulyandin G.A. Experience in applying the GPR method in the exploration of placer gold deposits of Yakutia. Advances in modern natural science, 2018. No. 11. pp. 160-165. (In Russ.)

9. Chotchaev Kh. O., Burdzieva O.G., Zaalishvili V.B. Zoning of high mountainous areas by geoecological loads caused by geodynamic and climatic influences. Geology and Geophysics of Russian South, 2021. No. 11 (1). pp. 81-94. DOI: 10.46698/VNC.2021.15.66.007. (In Russ.)

10. Sharafeldin H. E. Late-orogenic gold deposits of Egypt. Gornye nauki i tehnologii. Mining science and technology, 2018. Vol. 1, pp. 89-96. DOI: 10.17073/2500-0632-2018-1-89-96.

11. Augustin J., Gaboury D. Multi-stage and multi-sourced fluid and gold in the formation of orogenic gold deposits in the world-class Mana district of Burkina Faso - Revealed by LA-ICPMS analysis of pyrites and arsenopyrites. Ore Geology Reviews, 2018. Vol. 104. pp. 495-521. DOI: 0.1016/j. oregeorev. 2018.11.011.

12. Ganapathy G.P., Zaalishvili V.B., Chandrasekaran S.S., Melkov, D.A. Integrated monitoring of slope process in India and Russia. Sustainable Development of Mountain Territories, 2020. No. 12 (4). pp. 572-581. DOI: 10.21177/1998-4502-2020-12-4-572-581.

13. Luo D., Zeng G. Application and effects of singularity analysis in evaluating the denudation degree of Carlin-type gold deposits in southwest Guizhou, China. Ore Geology Reviews, 2018. Vol. 96. pp. 164-180. DOI: 10.1016/j. oregeorev. 2018.04.018.

14. Nassani A.A., Aldakhil A.M., Zaman K. Ecological footprints jeopardy for mineral resource extraction: Efficient use of energy, financial development and insurance services to conserve natural resources. Resources Policy, 2021. Vol. 74. №. 102271. DOI: 10.1016/j. resourpol. 2021.102271.

15. Sebutsoe T. C., Musingwini C. Characterizing a mining production system for decisionmaking purposes in a platinum mine. The Journal of the Southern African Institute of Mining and Metallurgy, 2017. Vol. 117. pp. 199-206. 
16. Sinclair L., Thompson J. In situ leaching of copper: Challenges and future prospects. Hydrometallurgy, 2015. Vol. 157. pp. 306-324. DOI: 10.1016/j. hydromet. 2015.08.022.

17. Song X., Pettersen J.B., Pedersen K. B., Roberg S. Comparative life cycle assessment of tailings management and energy scenarios for a copperore mine: A case study in Northern Norway. Journal of Cleaner Production, 2017. Vol. 16415. pp. 892-904.

18. Tyulenev M.A., Zhironkin S.A., Garina E.A. The method of coal losses reducing at mining by shovels. International Journal of Mining and Mineral Engineering, 2016. № 7 (4). pp. 363-370. DOI: 10.1504/IJMME. 2016.079990.

19. Tyulenev M.A., Markov S.O., Gasanov M.A., Zhironkin, S.A. Numerical Modeling in the Structural Study of Technogenic Rock Array. Geotechnical and Geological Engineering, 2018. №36 (5). pp. 2789-2797. DOI: 10.1007/s10706-018-0501-3.

20. Zhukovskiy Y., Batueva D., Buldysko A., Shabalov M. Motivation towards energy saving by means of IoT personal energy manager platform. Journal of Physics: Conference Series, 2019. No. 333 (6). DOI: 10.1088/1742-6596/1333/6/062033. 